\title{
顎関節症に対するスプリント療法と関節腔内注入療法に関する検討
}

\author{
峰野泰久・山内隆之・佐藤公治・村井 猛 \\ 筧 錦子・桑原未代子・日比五郎・岡達
}

\section{Effects of occlusal splints and intra-articular injection therapy in temporomandibular joint arthrosis}

\author{
Yasuhisa Mineno - Takayuki Yamauchi $\cdot$ Kohji Satoh \\ Takeshi MUraI - Kinko KaKeHI • Miyoko Kuwahara \\ Goroh HiBI • Tohru OKa
}

\begin{abstract}
Occlusal splint therapy and intra-articular injection therapy were administered to 30 patients ( 3 males and 27 females, average 35 years 10 months) with TMJ arthrosis in whom conservative therapy such as drug therapy and physiotherapy had been ineffective. The clinical efficacy of the two therapies was evaluated.

1. Occlusal splint therapy was applied to 28 patients, and it consisted of relaxation splint in $14.3 \%$, stabilization splint in $46.4 \%$, resilient splint in $14.3 \%$, pivoting splint in $7.1 \%$ and other splints in $17.9 \%$, stabilization splint therapy was thus applied to the largest number of patients. The efficacy rate as a function of the kind of splint was $75.0 \%$ for relaxation splint, $61.5 \%$ for stabilization splint, $75.0 \%$ for resilient splint, $50.0 \%$ for pivoting splint and $60.0 \%$ for other types of splint. The overall efficacy rate was thus a high $64.3 \%$.

2. Intra-articular injection therapy was performed in a total of 7 patients, consisting of triamcinolone acetonide in 5 patients and glycosaminoglycan polysulphate in 2 patients. The effect lasted more than 2 weeks in out of 5 cases of triamcinolone acetonide and 2 out of 2 cases of glycosminoglycan polysulphate.
\end{abstract}

Key words: TMJ arthrosis, occlusal splint, intra-articular injection therapy

緒

\section{$\overline{\overline{⿳ 亠 二 口}}$}

靧関節症に対する保存的療法にはさまざまなものがあ り，その選択が重要である。そのらちスプリント療法は 可巡的療法としての臨床成績から賞用され，またいっぽ 5 , 関節腔内注入療法は各種保存的療法が奏効しない関 節疼痛症状の速効的な臨床効果が評価されている。䫇関 節症に対するこのような保存的療法は, 顎関節症患者の

藤田学夌保健衛生大学医学部葜科口腔外科

（主任：岡達教授）

Department of Dentistry and Oral Surgery, School of Medicine, Fujita-Gakuen Health University (Chief: Prof. Tohru Oka)

受付日：昭和62年 7 月 24 日
増加に伴い今後ますます重要なものとなる。これまでス プリント療法の臨床的検討は, 歯科補綴学の領域で比較 的多くみられる ( $^{1 \sim 6)}$ ものの口腔外科領域では少ない、7,8). また，関節腔内注入療法については副腎皮質ステロイド 剂の関節腔内注入療法の報告 $9,10,11)$ が散見されるが，た とえば関節軟骨保護剂の報告例はない。

今回，われわれは顎関節症と診断された患者30例に対 しスプリント療法と関節腔内注入療法を応用し, 症型と の関連およびその臨床効果などを検討したので報告す る.

\section{対象症例および方法}

対象症例は昭和60年 7 月より以降， 1 年間に藤田学園 保健衙生大学病院
を受診し，靧関節症と診 
断されスプリント療法および関節腔内注入療法を施行 して，経過を観察し得た13歳から71歳までの30症例であ る(表1).

症例は顎関節研究会「顎関節症に関する小委員会案 ${ }^{12)} 」$ に従って区分すると，I 型 4 例 (13.3\%)，II 型 10 例 $(33.3 \%), \mathbb{I}$ 型14例 $(46.7 \%), \mathrm{IV}$ 型2 例 $(6.7 \%)$ とな り, II 型, III 型の慢性外傷性病変, 関節円板の異常症例 が多くを占めた（表 2 ）.

スプリント療法は, 初診後 1 週または 2 週間の初期薬 物療法にて関節痛, 雑音および開口障害などの症状が改 善しなかった28例に施行した. Krough-Poulsen'1による スプリントの分類（表 3 ）に従って区分すると, relaxation splint 4 例, stabilization splint 13 例, resilient splint 4 例, pivoting splint 2 例とこのいずれにも属さな

表 1 対象症例

\begin{tabular}{c|c|c}
\hline 男性 & 女性 & 計 \\
\hline 3 & 27 & 30 例 \\
$(10.0)$ & $(90.0)$ & $(100.0 \%)$
\end{tabular}

期間：昭和 60 年 7 月より同 61 年 6 月の 1 年間

年齡分布 : 13歳から71歳まで

平均年齢：35歳10か月
い形式のものを others type と称して 5 例に使用した. 関節腔内注入療法は，いずれも薬物療法，スプリント 療法に対し効果を認めない7 例に行った。術式は大西 ${ }^{13)}$ の方法に準じ $0.5 \%$ 塩酸りドカイン液（エピネフリン非 添加）を上関節腔に注入，パンピング確認後，副腎皮質 ステロイド㶡（トリアムシノロンアセトニド水性眯濁注 射液：管注用 ケナコルトR-A）は $0.5 \mathrm{ml} 20 \mathrm{mg}$ を 5 例に，また，関節軟骨保護剂（ムコ多糖体多硫酸エステ ル 注射液：アルテパロン®）は $0.5 \mathrm{ml} 25 \mathrm{mg}$ を 2 例 に使用した。

効果判定基準は, 顎関節部疼痛, 筋緊張, 開口障害お よび側方運動障害, 顎関節雑音の各症状をその程度によ りそれぞれサ，十。土，一とし，スプリント療法の場合 は治療後 2 か月および 2.5 か月における治療効果を, 著 効, 有効, やや有効, 無効の 4 段階に分け判定した（表 4 ).なお，関節腔内注入療法の効果の判定は，別途， 表 5 に示すよらに効果発現とその持続期間を主たる指標 とした。

\section{成績}

\section{1. スプリント別の治療効果}

表 6 に適応症例数と有効症例数を各症型ごとに示す.

表 2 病型分類

\begin{tabular}{|c|c|c|c|c|c|}
\hline I 型 & II 型 & III 型 & IV 型 & $\mathrm{V}$ 型 & \\
\hline 咀嚼笳障害 & 慢性外㩐性病変 & 顎関節内障 & 退行性病变 & 精神的因子 & 計 \\
\hline $\begin{array}{c}4 \\
(13.3)\end{array}$ & $\begin{array}{c}10 \\
(33.3)\end{array}$ & $\begin{array}{c}14 \\
(46.7)\end{array}$ & $\begin{array}{c}2 \\
(\mp 6.7)\end{array}$ & - & $\begin{array}{c}30 \text { 例 } \\
(100.0 \%)\end{array}$ \\
\hline
\end{tabular}

表 3 スプリントの分類

(Krough-Poulsen ${ }^{1)}$ に隻ずる)

1. Relaxation splint（前歯接触型硬性レジン宋） 前菌部のみ接触し，臼菌部は離開するタイプ

2. Stabilization splint（全宩接触型硬性レシン床） すべての咬合位で均等な接触を得るもの.

3. Resilient splint (軟性レシン床) 上下顎いずれかの咬合面全体を被覆するもの で，全部を軟性レシンによるものと，咬合面部 のみのものとがある。

4. Pivoting splint (有挺子床)

両側最後臼芼部の咬合面部に小㔖起を設けるも ので，犬料部を矯正用輪コムで牽引して顎関節 腔の払大をはかるものである。

5. Others type
(1) 誘導型スプリント
（2）円板整位型スプリント

表 4 効果判定基準

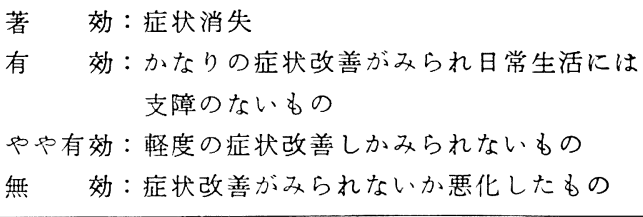

表 5 効果判定基淮

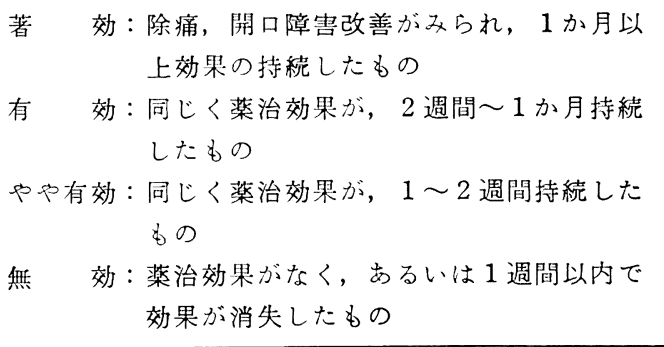


表 6 スプリントの種類と有効率

\begin{tabular}{|c|c|c|c|c|c|c|}
\hline & \multicolumn{5}{|c|}{ 顎関節症の分類 } & \\
\hline & I 型 & II 型 & III 型 & IV 型 & $\mathrm{V}$ 型 & $\begin{array}{l}\text { 有効症例／ } \\
\text { 適底症例 } \\
\text { (有効率) }\end{array}$ \\
\hline Relaxation splint & $1 / 1$ & $1 / 1$ & $1 / 2$ & - & - & $3 / 4$ 例 \\
\hline Stabilization splint & - & $4 / 7$ & $3 / 5$ & $1 / 1$ & - & $8 / 13$ 例 \\
\hline Resilient splint & - & $1 / 1$ & $2 / 3$ & - & - & $3 / 4$ 例 \\
\hline Pivoting splint & - & - & $0 / 1$ & $1 / 1$ & - & $1 / 2$ 例 \\
\hline Others type & $2 / 3$ & $1 / 1$ & $0 / 1$ & - & - & 3/5例 \\
\hline $\begin{array}{c}\text { 有効症例／適応症 } \\
\text { (有効率) }\end{array}$ & $3 / 4$ & $7 / 10$ & $6 / 12$ & $2 / 2$ & - & $\begin{array}{l}18 / 28 \text { 例 } \\
(64.3 \%)\end{array}$ \\
\hline
\end{tabular}

すなわち, relaxation splint は I 型 1 例, II 型 1 例, III 型 2 例の計 4 例 $(14.3 \%)$ に，また stabilization splint は II 型 7 例, II 型 5 例, IV 型 1 例の計 13 例 $(46.4 \%)$, resilient splint は II 型 1 例, $\mathbb{1}$ II 型 3 例の計 4 例 (14.3 $\%$, pivoting splint は II 型 1 例, $\mathbb{N}$ 型 1 例の計 2 例 (7.1\%), others は I 型 3 例, II 型 1 例, II 型 1 例の計 5 例（17.9\%）にそれぞれ装用した。その結果， stabilization splint をもっとも多く適用していた。治療効果を 全般的にみると，著効，有効を合わせた有効率では，28 例中 18 例 $64.3 \%$ であった。症型別の有効症例数は I 型 $3 / 4$ 例, II 型 $7 / 10$ 例, II 型 $6 / 12$ 例, IV 型 $2 / 2$ 例であり, また，スプリント別の有効症例数は, relaxation splint $3 / 4$ 例, stabilization splint $8 / 13$ 例, resilient splint $3 / 4$ 例, pivoting splint $1 / 2$ 例, others type $3 / 5$ 例であっ た.

ここで，本症における主症状の関節痛と関節雑音に対 する効果をみると，靧関節症 II 型の䋶関節部疼痛を主体 とする病態では $7 / 10$ 例に有効であり，また䋶関節症 III 型の関節雑音を主体とする病変では $6 / 12$ 例に効果を認 めた。

次㳊，代表的な症例を述べる。

症例 1

患 者: 藏 男性.

主 訴: 左顎関節部開口時痛.

既往歴：特記事項はない。

現病歴: 昭和 61 年 9 月, 左顎関節クリック初発. 1 か 月後, 同部の開口時痛発現. 以後この症状は不变. 同年 12月日日当科初診.

現 症: 左靧関節に相反性クリックがあり，無痛開口

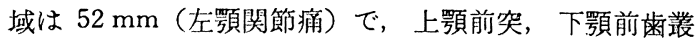
生の不正咬合が存在した。第 1 大臼歯の咬合は右 Angle

III級. 左 Angle I 級であった。

診 断: 左顎関節症型.
治 療: 昭和61年12月口日当科初診. 12月ロ日円板整 位型スプリント装着. 昭和 62 年 1 月曰日関節雑音消失.

4 月曰日スプリント除去.

症例 2

患 者: 歳 女性.

主 訴: 開口障害.

既往歴：特記事項はない。

現病歴: 昭和60年 7 月頃より左靧関節部痛, 開口障害 発現. 同年 9 月曰日当科初診.

現 症: 左䫇関節部圧痛, 無痛開口域 $22 \mathrm{~mm}$, 有痛最 大開口域 $26 \mathrm{~mm}$ であった。

診 断: 左靧関節症 II 型.

治 療: 60 年 9 月日 stabilization splint を装着.

11 月 6 日, 顎関節部疼痛 $($ (一), 開口 $45 \mathrm{~mm}$ となり, そ の後の経過も良好である。

\section{2. 関節腔内注入療法と治療効果}

関節腔内注入療法は各種保存的療法にて症状の軽減を みない７例に施行した，副腎皮質ステロイド剂は㖽関節 症 II 型 2 例, III 型 3 例の計 5 例に使用し, 関節軟骨保護 剂はIVI型のみ 2 例に用いた。これを表 5 のごとき効果判 定基準を設けて有効症例数をみると, 副腎皮質ステロ1 ド阂に打いて $3 / 5$ 例, 関節軟骨保護剤では $\mathbb{N}$ 型のみ $2 / 2$ 例 であった，症型別の有効症例数は， II 型 $1 / 2$ 例， II 型 $2 / 3$ 例, VI 型 $2 / 2$ 例であった.

\section{症例 3}

患 者：歳 女性.

主 訴：左買関節部痛。

既往歴：特記事項はない。

現病歴: 昭和 59 年 11 月頃, 左買関節部にクリック発 現. 昭和 60 年 1 月, 左顎関節部痛. 同年 8 月日日当科初 診.

現 症: 左咬筋に圧痛, 開口域 $21 \mathrm{~mm}$ にて左顎関節 部痛。クリック (-). 


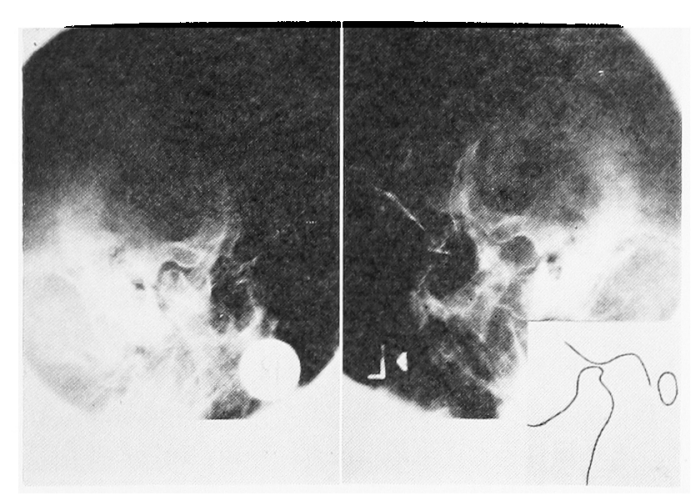

写真 1

診 断: 左額関節症 II 型.

治 療: 昭和60年 8 月日日 resilient splint装着, 筋訓 練療法開始，症状軽快せず，8月日日左罘関節に対し副 腎皮質ステロイド剤の関節腔内注入療法施行。鎮痛効果 を認めその後も持続し，10月日開口域 $40 \mathrm{~mm}$ となっ た.

\section{症例 4}

症 例: 䨓 女性.

主 訴: 開口障害.

既往歴：解離性大動哌瘤，喘息にて本学内科入院中.

現病歴：昭和58年 8 月頃より，開口時左䫟関節部痛発 現するも放置。昭和60年10月日日当科初診.

現 症：左咬筇，側頭筋に違和感，開口 $30 \mathrm{~mm} \mathrm{Kて}$ 左顎関節部痛, 最大開口時下顎正中は左方へ約 $2 \mathrm{~mm}$ 偏 位した，関節雑音を認めず，レントゲン的には左下顎頭 に osteophyte を認めた（写真 1). RA (一).

\section{診 断 : 顎関節症VI型.}

治 療：昭和60年10月 日下顎 resilient splint 装着 するも症状軽減せず，11月因左上関節腔に関節軟骨保 讙剤を関注. 注射後 2 日目より関節痛は著明に軽減し， それに伴い開口障害の改善を認めた。 以後 pivoting splint を併用乙鎮痛の維持を図った，昭和61年 1 月曰日 再度左上顎関節腔に関節軟骨保護剤を関注，以後 2 名月 にわたり経過良好であった。

\section{考察}

\section{1. スプリント療法について}

買関節病に対するスプリント療法はその簡便性，有効 性ゆえに重要な位置を占めている，Krough-Poulsen') はスプリントを (1) Relaxation splint (2) Stabilization splint (3) Resilient splint (4) Pivoting splint 4 型に分 けその適応を詳述している，われわれは，これに上記い ずれにも属さないO Others type を追加しスプリントを 5 種類に類型化し，臨床使用してみた。
その結果，スブリントの全体での有効率は $64.3 \%$ で あるが，このらちるっとも多く使用した stabilization splint を13例の有効率は61.5\%であった。このタイプは 全齿接触型でわれわれは頿関節症II 型，II型，V型に用 い広い適応があるとの印象を得ているが，Carraro ら22) はこのタイプの有效率を $82.4 \%$ と述べ，また本邦です埜 ロら ${ }^{21}$ の60\%，大西7 の78\%との報告がある.

対症状的にみると，このタイプのスプリントの効果は 雑音と疼痛緩解がほぼ等価を示していた。

次に relaxation splint（前崡接触型）は顠関節症 I, II， III型の 4 例に用い，主たる狙いはＩ型では筋㗨張の 緩和，他の型では鑑別診断の資料を獲得するためであっ た. その結果， $3 / 4$ 例の有效症例数が示された。

他の pivoting splint および resilient splint について は考察するに足る症例数ではないので今後の検討課題と したい.

以上のスプリントの作用機序としては，下買を機能的 に安定させ，(1) 顎関節腔の挔大，下顎頭の結合王迫の 除去 (2) 負担過重の除去 (3) 関節包，鞄帯を伸展させ拘 縮を防止する (4) 歯根膜, 顎関節の感覚受容器の求心性 インパルスの強さを变光筋緊張を除く (5) 心理的作用な どが報告されているる ${ }^{3,7)}$.

少数例ではあるがスプリント装着前後のレントゲン的 観察では，下䫛窩内に打外顎頭の位置的変化がみら れることから，上述の作用機序のらち(1)，(2)系の効果は 確かに存在するものと考えられた。

この場合のスプリントの咬合挙上量に関しては，種々 の意見があるが，臨佅的には装着時に安静位付近で上下 䫇が接触状態を保つ程度 く，妥当な量であらら。

いっぽう，スプリントの材質については，かつて軟性 レシンも用いられていたが，舌のもて遊び癖をひきおこ し5，ブラキシズムを増強させる3ので現在は硬性レジ ンが多く用いられる傾向にあり，われわれも最近ではこ のタイプを賞用している。また，その色は審美性，適合 状態の判定性より透明なるのが用いられる。そして, 加 熱重合レジンを推奖する報告 ${ }^{3,5)}$, 即時重合レジンで可 とする報告2)などがあるが即重レジンで十分と思われ た.

スプリントを上下買どちらに装用するかについては,

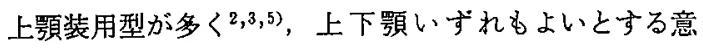

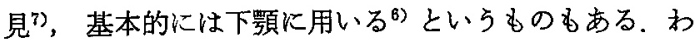
れわれは，舌感扣よびスプリントの安定維持の観点より 上顴装用を基本として大きな問題はないと考えている.

スプリント応用の実際，とりわけその治潦計画につい ては，丸山4 ${ }^{4}$ ，小林 ${ }^{5 》}$ にる詳細な記述がある。すなわ ちその大要は，(1) 歯や歯周組織の疾患があれば，その 処直を行う (2) 大きな咬頭干涉があればこれを除去する (3) Relaxation splintを診断を兼称昼夜連続 2 週間装 
用. 軟性食物の摂取, ブラッシングの強化, 1 日 1 回装 置の清掃を指示，食物摂取時に苦痛を訴える症例，会話 を職業とする症例では，食事中または仕事中これをはず し，その分期間を延長する。これで症状軽减すれば咬合 の関与が診断でき, 効果のなかったものは次のステップ へ進む (4) Stabilization splint を $2 \sim 4$ 週間装用する.昼 間の使用が不可能であれば夜間のみ装着させ期間を 3 〜 4 倍に延長する。調整は中心位閉口と歯牙タッピング時 に接触するように最初は $4 \sim 5$ 日後, その後は 1 週間ご とに削合し，下顎偏位が修正されていく場合には即重レ ジンの追加も必要である。(5)咬合調整(6)咬合再構成と している.このなかでの問題点は(6)咬合再構成である. この面での治療は歯科補緅との共同診療が必要となる.

したがって，口腔外科の診療は(5)までにとどめ，その後 の咬合再構成の時期判断および方法などは, よりいっそ ら慎重な計画と観察に基つかねばならない，急速な補経 治療による咬合状態の改変は新たな関節周囲の病態をつ くりだすものとして無視できない23).

\section{2. 関節腔内注入療法について}

(1) 注入薬剤について

保存的治療が奏効しない症例に対し副腎皮質ステロイ ド成 (triamcinolone acetonide：ケナコルト囚-A)を 5 例, 関節軟骨保護剤（ムコ多糖体多硫酸エステル：アル テパロン®）を2例に関注した。

筋注用ヶナコルト®- $\mathrm{A}$ は水性眯濁液で $1 \mathrm{~m} l$ 中の組成 は次のとおりである14,15)

Triamcinolone acetonide

Benzyl alcohol

$40 \mathrm{mg}$

Sodium carboxymethyl cellulose

$9 \mathrm{mg}$

Polysorbate 80

$7.5 \mathrm{mg}$

$0.4 \mathrm{mg}$

Sodium chloride

適量

$\mathrm{pH}$ 5〜7

図 1 のごとき化学構造を有し，局所使用による抗炎症 作用は, hydrocortizone acetate の約40倍, predonisolone の約10倍であり，鉱質代謝作用などの二次的作用はきわ めて少なく，毒性は非常に低いといわれている，効果の 持続作用は従来のものに比して長いという特長をもって いる.

いっぽう，アルテパロン®はムコ多糖体多硫酸エステ ル注射液で, $1 \mathrm{~m} l$ 中ムコ多糖体多硫酸エステル $50 \mathrm{mg}$ を含有する。作用機序としては，ライソゾーム系酵䋕活 性の抑制作用 ${ }^{16)}$ ，変性軟骨の基質補強作用 ${ }^{17)}$, proteoglycan 合成の促進 ${ }^{18)}$ ，滑膜細胞のヒアルロン酸合成の 促進 ${ }^{19)}$ などがあり，ステロイド凮と比較して効果が持続 する傾向にあると報告されている17)

（2）関注法について

関注手技は大西 ${ }^{13)}$ の方法に準じて行うが，もっとも注 意すべきは注射部位よりの感染である，七川 ${ }^{20)}$ は感染の 可能性や微細結晶による炎症誘発の可能性を考虑すれ

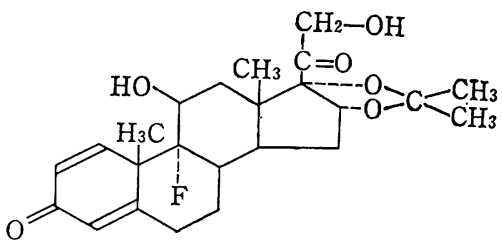

図 1 triamcinolone acetonide

ば，注入回数はできるだけ少なく，効果があればすぐ中 止し，注入間隔は1か月以上が望ましいと報告してい る。また田口ら ${ }^{11}$ は症例の選択，無菌的操作とともに関 注間隔は 1 か月以上に 1 回と長くし, 効果があればすぐ 中止することを強調している。われわれも注入にあたっ ては, 刺入部周囲の十分な剃毛, 消毒の無菌的操作とと もに注入回数をできるだけ少なくすることに留意してい る.

（3）適応および効果について

副腎皮質ステロイド剤の関注の適応に関して田ロら は, 内在性外傷および特発性外傷による顎関節症に対す る本法の有用性を報告し，関節包を含めた関節腔内に， ある程度の炎症病態の存在を推定している。岡 (2) $^{9}$ 関 節包内の炎症病態の局在は, 滑膜, 関節円板後方部な ど，とくに下顎頭の前方滑走運動に際して強く伸展する 部位にあると推論している，われわれは，各種保存的治 療により症状の軽快をみない顎関節症をその適応症例と 考えている。副腎皮質ステロイド斉の関注の有効症例数 は $3 / 5$ 例で, そのらちわけは顎関節症 II 型 $1 / 2$ 例, 買関 節症 III 型 $2 / 3$ 例で II 型で比較的よい結果を得ている.

田口ら ${ }^{11)}$ は本法の有効率は64.8\%で，とりわけ，経過 の長い慢性例には有効例が少なかったと述べている。こ のことについては, 関節腔内の micro trauma, minor inflammation が長期に及んだ場合，それがより進展し た器質的変化をもたらし，副腎皮質ステロイド阂の薬治 効果が低くなると報告している，以上の所見から，われ われは病変が長期に及び㖽関節部の器質的変化が疑われ る面関節症 IV 型に対して, 関節軟骨保護剂（アルテパロ ン囚）の関注を行い少数例ではあるが高い有効率を得て いる.

以上より今回の検討において，顎関節症の治療におけ るスプリント療法扣よび関節腔内注入療法の適応症とし て以下のものがあげられた。

1. スプリント療法では, 咬合性か否かの鑑別を行う場 合，および㴿関節症 I 型に対しては relaxation splint, 顎関節症 II 型， II 型には stabilization splint，顎関節症 III型のなかでも相反性クリックを有する症例には円板整 位型スプリントがそれぞれ有効であった。

2. 関節腔内注入療法では, 顎関節症 II 型, II 型に対 しては副腎皮質ステロイド斉，また顎関節症 $\mathbb{V}$ 型に対し ては関節軟骨保護剂の関注の有用性が高かった。 
結

語

顎関節症患者のらち薬物および理学療法などの保存的 療法が奏効しない30例（男性 3 例，女性27例，平均年齢 35歳10か月）に対し，スプリント療法および関節腔内注 入療法を施行し臨床的検討を加えた。 その成績は次のよ らに要約される。

1. スプリントは28 例に施行し, その5ちわけは, relaxation splint $14.3 \%$, stabilization splint $46.4 \%$, resilient splint $14.3 \%$, pivoting splint $7.1 \%$, others $17.9 \%$ stabilization splint をもっとも多く適用して いた. スプリントの種類別の有効症例数は relaxation splint $3 / 4$ 例, stabilization splint $8 / 13$ 例, resilient splint $3 / 4$ 例, pivoting splint $1 / 2$ 例, others type $3 / 5$ 例, 全 体では64.3\%の高い有効率を示した.

2. 関節腔内注入療法は副腎皮質ステロイド阂 5 例, 関節軟骨保護斉 2 例の計 7 例に施行し, その有効症例数 は副腎皮質ステロイド斉 $3 / 5$ 例, 関節軟骨保護剂 $2 / 2$ 例 であった。

本論文の要旨は，昭和61年10月回第29回日本口腔科 学会中部地方会（松本）に打いて発表した。

\section{引用文 献}

1) Krough-Poulsen, W.G.: Management of the occlusion of the teeth. Facial pain and mandibular dysfunction. WB Saunders Co, Philadelphia, London, Toronto, 1968, p 236279.

2）藍稔，古谷良一：ハイトプレート（スプリ ント）について。新菌潮 6: 219-229 1972.

3）小林義典 : Bite plane おょび Occlusal splint （s）応用に上る可逆療法。日本菌科評論 392 : 57-69 1975.

4）丸山㴊郎：顎関節症の治療, 補綴の立場から. 耳鼻臨床 73: 1809-1812 1980.

5）小林義典：スプリントによる治療. デンタルダ イヤモンド 7: 98-103 1982.

6）渡辺誠，佐々木啓一，他：顎関節症のスプリ ント療法。菌界展望 63：29-38 1984.

7）大西正棇：顎関節症に対する罰間率引療法につ いて. デンタルダイヤモンド 7: 168-172 1982.

8) 柴田考典, 伊藤司, 他：顎関節内症の病態, 診断, 治療. the Quintessence 14: 61-72 1985.
9）岡逞, 田口望：副婜皮所ステロイド風関 節腔内注入療法の効果からみた顎関節症の病 態. 绦界展望 63：57-64 1984.

10) Wenneberg, B. and Kopp. S.: Short term effect of intra-articular injections of a corticosteroid on temporomandibular joint pain and dysfunction. Swed Dent J 2: 189-196 1978.

11）田口望, 小川正義, 他：顎関節症に打ける副 腎皮質ステロイド阂の顎関節腔内注入療法に関 する検討。日口外誌 30：430-437 1984.

12）小野尊睦, 岡達, 他: 顎関節症分類案. 顎 関節研究会第 7 回総会誌: 巻末 1987.

13）大西正俊：顎関節腔内穿刺法とその応用に関す る臨床的研究。口病誌 37：178-207 1970 .

14）筋注用ヶナコルトーA文献集 71-74 1965.

15）笳注用ヶナコルトーA 文献集 75-78 1965.

16) Greiling, H. and Kaneko, M.: Die Hemmung lysosomaler Enzyme durch einen Glykosaminoglykanpolysulfat. Arzneim Forsch 23: 5935971973.

17) Richter, A.: Beitrag zur Therapie von Gelenkerkrankungen experimentele und klinische Erfahrungen mit einem Mukopolysaccharidpolyschwefelsäureester. Med Monatsschr 24: 121-125 1970.

18) Adam, M.: Contribution to the mode of actin of glycosaminoglycan polysulphate (GAGPS) upon human osteoarthrotic cartilage. Biochemical study of the collagen and proteoglycan turnover. Arzneim Forschz 30: 1730-1732 1980.

19) Greiling, H.: Biochemische Untersuchungen zur Wirkungswelse des Arteparon. Dettmer, N., Greiling, H. and Sensch, K.H. (Ed.): Internationales Arzneimittelsymposium Arteparon, EULAR Verlag, Basal, 1980, p 1118.

20）七川缼次（梅原千治監修）：副腎皮質ステロイ ド療法。日本メルク万有, 東京, 1982, 403-421 頁.

21）埜口五十雄, 石橋克禮, 他 : 顎関節症の臨床一 口腔外科的立場から一. 日本透科評論 401:30411976.

22) Carraro, J.F. and Caffesse, R.G.: Effect of occlusal splints on TMJ symptomatology. J Prosthet Dent 40: 563-566 1978.

23）伊藤武志, 宮村一弘, 他：補緅物に上り惹起し た顎関節症の 1 治験例。補経臨床 4:71-81 1971. 